\title{
Plate IX.
}

Fig. 1. Placunopsis subjurensis: $a$, umbonal aspect; $b$, lateral aspect: natural size.

2. Placunopsis undulata, natural size.

3. Mytilus (Lithodomus) Stowianus: a, posterior moiety of the shell; $b$, anterior of another specimen: both of the natural size.

4. Pinna Sharpei, natural size.

5. Lima obliquissima, natural size.

6. Pecten projectus, natural size.

7. Astarte Pinchiniana: $a$, lateral aspect; $b$, view of the dorsal region; natural size.

8. Crassatella complicata, natural size.

9. Arca Jonesii, natural size.

10. Vermilia Pinchiniana: $a$, attached portion ; $b$, free portion; $c$, transverse section of the same: natural sizes.

11. Mytilus Rubidgei, natural size.

2. Further Remariss upon the Retation of the Chiclesford Beds to the Fluviomarine Crag. By the Rev. O. Fisher, M.A., F.G.S.

\section{(Abstract.)}

THe author dissents from the interpretation of two pit-sections, one on Aldringham Common, the other near Henham Park Farm, given by Mr. Searles Wood in his paper "On the Structure of the Red Crag." Mr. Fisher admits that the former is at a higher level than the Thorpe Crag-pit, and the latter than the Wangford Crag; but he denies that the loam on Aldringham Common is Chillesford clay, and is doubtful whether even that at Henham Park Farm belongs to that deposit. Granting, however, that the loam in the latter case is really Chillesford clay, the author states that it is probably carried under the Wangford Crag by a northern dip. Thus he considers that neither of these sections contains indisputable evidence of the superposition of the Chillesford clay to the Fluviomarine Crag. He also expresses a doubt of the crag at Bulchamp being a continuation of the Wangford bed, and states that it much more resembles the Mya-bed as seen at Yarn Hill.

P.S. A subsequent examination of the neighbourhood of Norwich in April 1867, led the author to admit the identity of the Mya-bed with the Upper Crag of Mr. Taylor, as seen at Toft Monks and Bramerton; and consequently to abandon such of his published opinions as are inconsistent with that conclusion.-- - F.

\section{February 20, 1867.}

The Right Hon. the Earl de Grey and Ripon, 1 Carlton Gardens, S.W. ; Frank Clarkson, Esq., 27 Oakley-street, S.W.; James Diggens, Esq., Secretary to the Royal Albert Idiot Asylum; and Joseph Lucas, Esq., of the Geological Survey of Great Britain, Museum, Jermyn-street, S.W., were elected Fellows :-

The following communications were read:- 
1. On the Britisir Fossir Oxan. Part II. Bos longrfrows, Owen. By W. Boyd Dawrins, Esq., M.A. (Oxon.), F.R.S., F.G.S.

\section{ConTents.}

1. Introduction.

2. Charactors.

3. Synonyms.

4. Measurements.
5. Range in space and time.

6. Relation to domestic races.

7. Conclusion.

\section{Introduction.}

In the first part of this essay I have traced the gigantic Urus from the earliest Pleistocene times through the Prehistoric period, at least as far down as the 12th century after Christ. Now I propose to pass on to the consideration of the small British Short-horn, the Bos longifrons of Professor Owen, which, had it not been inserted among the Pleistocene Mammals in the recognized text-book, would not now be brought before the notice of the Geological Society. The accurate definition of a species and its range in space and time is of the highest importance. " Every form," says Dr. Falconer, " well ascertained becomes a powerful exponent, while ill-determined it is a fertile source of error." The truth of this is proved by the present case. Professor Owen's verdict has been accepted in England from the time of its publication in 1846; and Bos longifrons has been considered universally as much a Pleistocene Mammal as the Urus or Bison. Under these circumstances I feel bound to give my reasons for believing that the evidence in support of this conclusion is altogether insufficient, and that the name ought therefore to be struck out of all Pleistocene catalogues.

\section{Characters.}

Bos longifrons, as compared with B. urus, is characterized by Professor Owen by its small size, by the different currature of its small and short horns, by the smaller concavity, and often the flatness, of the forehead, and by the greater extent of the frontals beyond the orbits, before they join the nasal bones*. In addition to these there are other points of difference and agreement, considered by Dr. Rütimeyer $\uparrow$ and Professor Nilsson $\ddagger$ of specific value, which have eluded my search on the comparison of a very large number of specimens. The small size and the single upward curvature of the horn-cores are the only two salient points that I can recognize, on placing its remains side by side with the Urus and the larger domestic Oxen; and even these vanish on its comparison with the smaller domestic breeds. A very large number of skulls from the Irish turbaries, in the museum of the Royal Dublin Society, show a marked gradation in size and form, and constitute an unbroken series, with the Bos frontosus $\S$ of Nilsson at one end, and the more

* Brit. Foss. Mam. p. 508.

+ Fauna der Pfahlbauten der Schweiz. 4to. Basel.

¥ "On the extinct and existing Bovine Animals of Scandinavia," Annals and Mag. Nat. Hist. 2nd ser. vol. iv.1849, p. 351.

$\S$ Op. cit. p. 349. 
common variety of Bos longifrons at the other. The truth of the great variability of the so-called species, first brought home to me in Dublin in 1864, is amply confirmed in all the other cases of a large quantity of the remains having been brought together for comparison, as in the British and Oxford Museums, and in that of the Royal College of Surgeons. In consequence of this I am unable to assign any characters of specific value to the animal. Specific distinctions, indeed, based on size of horn, or of frontal sinuses, are proved to be totally devoid of value by the history of the Galloway breed of polled cattle, for which I am indebted to the Right Hon. the Earl of Selkirk, F.R.S.* One hundred and fifty years ago that breed was possessed of horns; but, owing to the greater market value of the few polled varieties among them, the latter were encouraged at the expense of the horned, until the whole breed became possessed of its present characters. The last trace of the horn in the breed is furnished by the Rer. W. Bingley, in 1809. "Some few of the animals," he writes, " in every other respect polled, have two little useless horns from two to four inches long, which hang down loose, and are not, as in other cattle, inserted into the skull" $\uparrow$. At the present day, in the purely bred Galloway beast, there is no trace of horn. Thus we have clear proof of the metamorphosis of a horned into a hornless breed, and, therefore, that even the possession of horns is not essentially characteristic of a given race of cattle.

For full details of the osseous structure of Bos longifrons I must refer to those of the domestic $\mathrm{Ox}$, Bos taurus, in the various books of Natural History, instead of bringing irrelevant matter before the. notice of the Society.

\section{SYNONYMS.}

The Bos longifrons of Owen is also termed the $B$. brachyceros, Owen, under which name the animal is known in France and Ger-

* " I have no distinct written record about the way the horns of the Galloway cattle were 'bred out,' as we cattle-breeders would say. - The breed, a hundred and fifty years ago, was not generally 'polled' i.e. without horns, though there were always a good many polled ones among them. Polled ones are found in every breed. My informant was an old man who died about thirty years ago, he being then near ninety. He was the son of the man who tended the cows for my grandfather, and had been employed among cattle all his life : in his old age, while still able to work, he tended my cows. His name was James Mc Kinnan, and he was a man whose recollections seemed always remarkably clear. "He had been with cattle as far as Norfolk, to St. Faith's fair. He told me that, in the days of his childhood, a Norfolk feeder, who bought many of the Galloway cattle, fancied those without horns, and would give $2 s$. $6 d$. or so more for a polled than for a horned beast. This set the fashion; and the people began first to look for polled bulls and none other; then they preferred the polled cows, \&c. \&c. to breed from; and thus the change was effected in, I believe, from 50 to 60 years. The horns of the Galloway beasts were very ugly, drooping, and as thick at the point as at the root. I have myself seen one or two beasts with horns like that; but now-a-days when horns appear, they are generally traced to some cross with an Irish brute. Those that are born polled, have a bump in the centre of the forehead, which is very hard and will break another bull's skulk for him."-Extract from a letter of the Earl of Selkirk, dated 6th March, 1867.

+ Memoirs of British Quadrupeds, p. 418. 8vo. London. 
many. This latter also was first proposed by Professor Owen in 1830, and in consequence of the name having been applied by Dr. Gray to an existing African species, was subsequently exchanged for the former. The Bos frontosus of Nilsson is proved by the series in Dublin, as stated above, to be a mere variety. All species, indeed, founded upon the greater or less development of the frontal sinuses, which is, in truth, the result of different age, sex, and habitat, must necessarily fall to the ground, whether they be Bears or Oxen.

\section{Measurements.}

The detailed measurements of the teeth and long bones I must reserve for the Table at the end of Part III., for the sake of comparison with those of the Urus and Bison. The skulls present great variations in size; but all can be distinguished at a glance from the gigantic ones of the Urus, with which they are found in Britain and Germany. In the following Table a few measurements, in inches, are given of two skulls, the one dredged up from the alluvium of the Thames, near Purfleet, the other derived from the peat-bogs of Scania, and described by Professor Nilsson*. The small size of the head of Bos longifrons can be realized by comparing it with the corresponding table of skull-measurements of Urus in the Quart. Journ. Geol. Soc. vol. xxii. p. 395.

\section{Measurements of two Skulls of Bos longifrons.}

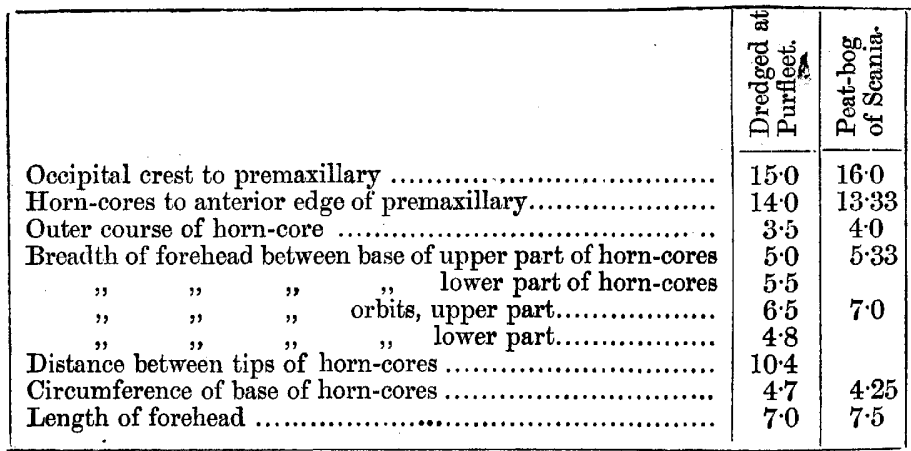

The horn-cores present very considerable variations in size and form, dependent probably on different age and sex. The first three measurements below are the maximum, mean, and minimum ones of upwards of forty-five horn-cores found at Richmond, Yorkshire, in a refuse-heap associated with the remains of Dog, Ursus arctos, Wild Boar, Horse,Red-deer, Fallow-deer, Sheep, and two varieties of Goat $\uparrow$. The fourth I found within a Romano-British tomb at Hardham $\neq$; the

* Op. cit. p. 353.

+ See Quart. Journ. Geol. Soc. vol. xxi. p. 493.

$\ddagger$ Sussex Archæol. Trans. vol. xvi. pp. 52-64. 
next two are taken from Professor Nilsson's valuable work, and the last two from the specimens in the British Museum.

Measurements of Horn-cores.

\begin{tabular}{|c|c|c|c|c|c|c|c|c|}
\hline & \multicolumn{3}{|c|}{ Richmond. } & 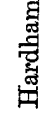 & 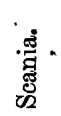 & 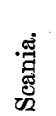 & 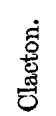 & 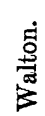 \\
\hline $\begin{array}{l}\text { Maximum length } \ldots . . . \\
\text { Basal circumference ... }\end{array}$ & $\begin{array}{l}5 \cdot 3 \\
4 \cdot 0\end{array}$ & $\begin{array}{l}3 \cdot 9 \\
3 \cdot 9\end{array}$ & $\begin{array}{l}2 \cdot 6 \\
3 \cdot 4\end{array}$ & $\begin{array}{l}4 \cdot 5 \\
5 \cdot 1\end{array}$ & $\overline{7 \cdot 1}$ & $\begin{array}{l}3 \cdot 0 \\
4 \cdot 18\end{array}$ & $\begin{array}{l}4 \cdot 0 \\
4 \cdot 5\end{array}$ & $4 \cdot 0$ \\
\hline
\end{tabular}

The horns themselves are found in the peat-bogs of Ireland. Two in my possession, for which I am indebted to the Right Hon. the Earl of Enniskillen, F.R.S., have respectively a basal measurement of $10.5+$ and 6.0 inches, and are 15.0 and 8.0 inches long. The one is of a dark and the other of a light brown colour. Another instance, also, of the horn being preserved is afforded by a specimen dug up in an old channel of the Cam, near Waterbeach, and now in the Oxford Museum. It also is of a brown colour. Professor Nilsson estimates the length of the animal in Scania as 6 fcet 8 inches, exclusive of the tail *. Unfortunately there are no materials for estimating its length and height in Britain. The size, however, of its bones proves it to have been the smallest of the $\mathrm{Ox}$ tribe.

\section{Range IN SPACE AND TIME.}

I must now pass to the consideration of the claims that the animal has to be inserted in the list of Pleistocene Mammals. Professor Owen writes that he found in the collection of the late Mr. John Brown, of Stanway, "some indubitable specimens of the Bos longifrons from freshwater deposits which are rich in the remains of Elephas and Rhinoceros." These consist of two skulls, the one from the "newer Pliocene deposits at Clacton," and the other from Walton-two localities on the Essex shore, which have furnished vast stores of the remains of the extinct Pachyderms. His argument is based on the supposition that all the fossil bones washed up by the sea at these two places are derived from the same beds, and are therefore of the same geological age. In the 'Introduction to the British Pleistocene Mammals,' in 1865, I expressed my doubts about the soundness of this view, which have been amply confirmed by a visit to Walton in the autumn of 1866 . The mammaliferous stratum lies at the bottom of the low cliffs between the high- and low-water mark; but this affords only a small percentage of the fossil remains. The great majority are left by the sea at low water, lying on a plateau of London Clay along with large Septaria, the wreck of the Red Crag, and waifs and strays of all kinds, and may have been washed out of deposits of two or three distinct ages. The condition of the remains I obtained with my own hands indicated at least two distinct 
origins. Some but lately washed out of the grey clay were of a pale grey colour, nearly devoid of gelatine, and to a certain extent mineralized; while others, light and porous, contained a large percentage of gelatine, and were of a reddish or sepia colour, which is invariably that assumed by remains imbedded in alluvial mud. The latter were probably derived from the alluvium hard by. Among them were a metacarpal of Goat or Sheep, and a small bovine humerus. A third class of remains were very heavy, stained black, and incrusted with a pyritous deposit, termed " pan," closely resembling that in the fossils from the Preglacial Forest-bed of Norfolk. How far this latter condition may be owing to the presence of large quantities of peroxide of iron (derived from the Red Crag) in the mud in which they were lying, and whether it be a chemical result of the decomposition of organic remains in sea-water full of peroxide, are points on which I can hazard no opinion. The skull from Walton, presented to the British Museum by Mr. Brown, of Stanway, and quoted by Professor $O_{w e n}$, is in precisely the same condition and of the same reddish colour as the bovine, caprine, and ovine remains above mentioned, and therefore was probably derived from the same source, whatever that may have been. It is not only waterworn, but also contains a few pebbles of shingle in one of the horn-cores, which proves that it was most certainly washed up by the sea. Its mineral condition forbids its derivation from the grey clay, and it cannot be classed with the black remains ; therefore it probably was washed out of the alluvium close by, which, throughout Western Europe, is full of the remains of the same animal. The presence of the Sheep or Goat affords collateral proof of this, as neither of these animals has been found in any Pleistocene deposit up to the present day ; and both apparently passed into Europe after the disappearance of the CaveHyena, Care-Bear, and all the extinct mammals, the Irish Elk being excepted. They characterize the Prehistoric deposits of France, Germany, and Scandinavia. The skull in question is therefore in all probability also of Prehistoric age, but not of oqual antiquity with the Elephas antiquus, leptorhine Rhinoceros, and Hippopotamus major, cast up by the sea on the same shore. The argument that would prove that it was in this particular case coeval with those extinct animals, might also be applied to the other waifs and strays, sea-weed, bits of wood, shells and the like, left between high-and low-water mark. The skull of Bos longifrons, found at Clacton, preserved also in the British Museum, falls into the same category as that of Walton. If, then, there is no direct evidence of the exact gisement of these skulls, the mere accident of their being associated with the remains of the extinct Mammals on the shore cannot be conclusive of their geological age; and therefore Professor Owen's view, founded on this assumption, must fall. A third locality is cited in the 'British Fossil Mammals,' of its occurrence with the Urus and Bison at Bricklehampton Bank, near Cropthorne, in Worcestershire*. Unfortunately $I$ have sought in vain for the remains on which the determination is based, as they, are neither named nor * Op. cit. p. 512 . 
the museum mentioned in which they are to be seen *. In the Hunterian Catalogue, Professor Owen has rightly ascribed the small bones from this locality to the Bison, the larger to the Urus; and they constitute a large and valuable series, affording a means of separating the former from the latter species. In no other museum can I find any other Bovine remains from this deposit. In the 'Life and Papers of H. E. Strickland' ', published by $\mathrm{Sir}$ W. Jardine in 1858, there is no mention of the Bos longifrons among the animals he found at Bricklehampton. The small sizes of the metacarpals and metatarsals of Bison, which closely resemble those of the British Shorthorn, may perhaps have caused Professor Owen, between the publication of the Hunterian Catalogue and that of the 'British Fossil Mammals,' to ascribe some of these to the latter animal. The horn-cores, which, in a disputed point, such as this, are alone to be relied upon, belong to the Bison; and therefore it is highly probable that the equivocal remains which, in the absence of horn-cores, might perhaps have been considered to be those of Bos longifrons, belong also to the former. Precisely the same argument applies to the Bos longifrons of Kirkdale $\$$, which is proved by the horn-cores to be the small variety of Bison-the Bison minor of Professor Owen. A fifth locality is given of its occurrence with the extinet Mammals, the gravel-pits of Kensington. In the absence, however, of direct proof that the remains of Boslongifrons were derived from the same undisturbed gravel as the Mammoth, the fact that the disturbed soil round London is full of the bones of Bos longifrons, which was the principal food of the inhabitants of the metropolis of Roman Britain, would strongly suggest that those in question were found in the superficial soil, and not in the gravel below. A parallel instance at Peckham, on a very careful examination, I found to be explained in this manner.

In the list of Mammals found at Fisherton $\$$, Bos longifrons is quoted as having been found in association with the Lemming, Spermophilus, Marmot, Tichorhine Rhinoceros, and other characteristic Postglacial species; but the remains aseribed to this animal and preserved in the Salisbury Museum, consisting of teeth and bones and not characteristic horn-cores, in truth belong to the smaller variety of Bison, B. minor of Professor Owen, which is very abundant in that locality. All the other cases quoted of its association with Pleistocene Mammals may be disposed of in the same way. The result of a careful examination of the mammalian remains in the collections of Great Britain and Ireland, is the discovery that there is no authentic evidence of the small Shorthorn having lived in Pleistocene times. It has never been found in Pleistocene deposits in France, Germany, or elsewhere in Europe. For these rea-

* Catalogue of Fossil Mammals, Nos. 1351-1393.

† Op. cit. p. 96. Hippopotamus major, Canis, and the Urus were adso found in the gravel and clay of the section.

$\ddagger$ Op. cit. p. 513 .

\& Quart, Journ. Geol. Soc. vol, xx. p. 192, and Catalogue of Blackmore Museum, Salisbury, 8vo. 
sons, therefore, I would suggest that the name be struck out of the list of Pleistocene Mammalia.

What, then, is its range in space and time? In the deposits that are termed Recent by Sir Charles Lyell, and which Mr. Sanford and myself have called Prehistoric, it is remarkably abundant. Throughout the temperate zone of Northern and Western Europe it ranged through the forests and plains in company with the Urus and the Bison. In Britain it was accompanied by the latter. It has left its bones in the lacustrine marls of Ireland, along with those of the Irish Elk and the Reindeer, and in the peat-bog of Hilgay, in Norfolk, with the Beaver. In the peaty mud near Newbury, in Berkshire, it is found along with the Wild Boar, Red Deer, Roe Deer, Wolf, Goat, Horse, Otter, Bear, Urus, and Water-rat. In the alluvia of rivers it is particularly abundant. Mr. Seeley, also, mentions its occurrence in the "older peat " of the Fenland with the same animals, under the name of Bos frontosus. It is commonly associated with human remains of a date anterior to the arrival of the Saxons. Dr. Thurnam's late discoveries prove that the tumuli of Wilts are full of its bones; the refuse-heaps of early Keltic villages, such as that of Stanlake*, in Berkshire, are composed of its remains. Around Roman stations and cities it is more abundant than any other animal, as, for example, Uriconium, Londinium, and Camulodunum. I have found it even in the graves of the Britons who were interred at Hardham, near Pulborough, in Sussex, during the Roman occupation $\uparrow_{\text {. The }}$ horn-cores and broken bones were lying in the same oaken chest which contained the ashes of the dead, drinking-vessels, garments, and sandals. Examples might be multiplied to prove its existence in large herds in Britain during the Bronze- and Stone-periods, and that it was the animal that supplied the bronze-using Kelts and their Roman conquerors with beef. In Prehistoric caverns it is very abundant, as in that of Dowkabotham $\ddagger$, in Yorkshire, explored by Mr. Farrar, M.P., and in several in Somerset, explored by Mr. Sanford and myself. Its metacarpals, from a black superficial deposit in Kents Hole, I have detected in the Museums of Oxford and the Geological Society; and had not the Rev. J. McEnery§ described the bed whence he obtained them, and had not their mineral condition been different from that of older remains found in the cave, it is very possible that they might have been quoted in confirmation of the view of the coexistence of the animal with Machairodus and other extinct Pleistocene Mammals found in a lower stratum.

On the continent, as in Great Britain, it is found around the dwellings and in the tombs of the Bronze- and Stone-folk. Nowhere is there the least evidence of its having a higher antiquity than the Neolithic age of Sir John Lubbock. It has not yet even been proved to have been living in Europe at the time a people

* Quart. Journ. Geol. Soc. vol. xxii. p. 479.

† Sussex Archæol. Trans. vol, xvi.

T The remains from this cavern are preserved in the Leeds Museum.

\$ 'Cavern Researches,' by the Rev, J, Me Enery, edited by E. Vivian, Esq. 4to. 1859 . 
more closely allied to the Esquimaux* than to any other dwelt in Aquitaine, and still less in the inconceivably more remote Pleistocene age.

\section{Relation to Domestic races.}

We have thus traced the animal through the Neolithic into the Bronze age, and thence into the period of the occupation of Britain by the Romans. Its relation to our domestic races of cattle still remains to be discussed. Professor Owen holds two contradictory opinions $\uparrow$ on this point. On the one hand, he believes that the Roman colonists imported into Britain their "already domesticated cattle," and that our breeds are their descendants. The fact that Bos longifrons is the only $\mathrm{Ox}$ found in the refuse-heaps, in not one or two but all the camps, cities, villas, and cemeteries that bear the impress of Roman civilization in Britain is sufficient to refute this hypothesis, which is unsupported by evidence derived either from history or archæology. On the other hand, he admits the probability that the Bos longifrons + was "the species domesticated by the Aborigines of Britain before the Roman invasion." That this animal was subject to man in the Neolithic and Bronze ages in Switzerland has been proved beyond all doubt by Dr. Rütimeyer §. In our own country, its numbers, as compared with those of the Reddeer and Roe-deer, in tumuli and Keltic villages, as, for example, in those cited above, in Wiltshire and Berkshire, prove that, probably in the Stone-age, and most certainly in the Bronze-age, it was kept in herds and slaughtered for man. When, therefore, the Romans conquered Britain, there was no need of their importing cattle from Italy; for they found a breed used to the climate and to the half-wild life which, in a country for the most part uncleared, must have been their lot. During the Roman occupation the animal was the staple meat of the country. When the Roman Empire yielded to the 'Teutonic invaders, who had been kept at bay for centuries by its power, and the legions in Britain were recalled for the defence of Italy, the Saxons, in a conflict that lasted for nearly 150 years, drove out the Romanized Kelts, burnt their towns and their villas, and compelled them to retreat to Wales, Cornwall, and the highlands of Scotland, taking, as far as they could, their cattle along with them. The fact

* The evidence in favour of their affinities with the Esquimaux is the following:-The identity of four of the harpoons, of fowling-spears, marrow-spoons, and scrapers; the habit of sculpturing animals on their implements; the absence of pottery ; the same method of crushing the bones of the animals slain in hunting, and their accumulation in one spot; the carelessness about the remains of their dead relatives; the fact that the food consisted chiefly of Reindeer, varied with the flesh of other animals, such as the Musk-sheep; and especially the small stature, as proved in the people of the Dordogne Caverns by the small-handled dagger figured by MM. Lartet and Christy in the 'Revue Archéologique.' This combination of characters is found, so far as I know, among no other people on the face of the earth except the Esquimanx; and therefore I cannot help believing that this people in South Gaul occupies the same relation to the Esquimaux, as the Musk-sheep and Reindeer, on which they lived, hold to those now living in the northern regions.
+ Op. cit. p. 500.
\$ Op. cit.
$\ddagger$ Op. cit. p. 514 . 
that we speak in a Teutonic and not a Romanic tengue proves how completely this depopulation of the more fertile provinces of Britain was effected. "Our forefathers," writes Mr. Freeman *, " appeared in the Isle of Britain purely as destroyers; nowhere else in Western Europe were the existing men and the existing institutions so utterly swept away. The English wiped out everything Celtic and everything Roman as thoroughly as everything Roman was wiped out of Africa by the Saracen conquerors of Carthage. A more fearful blow never fell on any nation than the landing of the Angles and Saxons was to the Celt of Britain."

The authors of the 'Pietish Chronicle' incidentally prove that the Saxons had expelled the Romanized Kelts from the Province of Valentia, that embraced the Lowlands of Scotland and part of Northumberland, when they state that the Highlanders of the seventh century, "descenderunt in Saxoniam." In this ruthless destruction of Roman civilization in Britain lies the explanation of the affinities of the small Welsh and Scotch cattle to Bos longifrons. They are in all probability the lineal descendants of those which the Romanized Kelts took with them in their retreat, and bear exactly the same relation to them as the modern Brit-Welsh does to the mixture of Keltic and Latin, which was the language of Roman Britain. During that war of nearly a century and a half, the variety seems to have died out in the parts of the country that were under Saxon rule; and I have sought in vain for any evidence of its reappearance from that time to the present. If I might hazard a guess at the immediate source whence our large cattle spring, I would suggest that the Lowlands between the mouth of the Rhine and Jutland, now famous for the large size of their cattle (such as those of Friesland), which was the ancient home of our Saxon ancestors, was also the place whence their cattle were imported. These larger cattle, as I have stated in my first essay, are, probably, derived from the Bos urus.

\section{Conclusion.}

The inferences to be drawn from the preceding pages are:-first, that the Bos longifrons has not yet been proved to have existed before the Prehistoric age, in the Bone-caves and alluvia of which it is found abundantly; and, secondly, that it is the ancestor of the small Highland and Welsh breeds. It is essentially the animal with which the Archæologists have to deal ; and its only claim for insertion in Geological Catalogues is the fact of its occurrence in the most modern of all the stratified deposits.

* 'History of the Norman Conquest of England,' by E. R. Freeman, M.A., vol. i. p. 20.8 ro. Oxford, 1867. 
2. On the Geologr of the Upper Part of the VaLiex of the Teign, Devonshire. By G. Wareing Ormeron, Esq., M.A., F.G.S.

[The publication of this paper is unavoidably deferred.]

\section{(Abstract.)}

THE district noticed in this paper lies to the north of Bovey Tracey. The anthor describes the courses of the Teign and its feeders, and the strata traversed by those streams, namely, Granite and Carbonifcrous Limestone. Gravels are occasionally found, which the author regards as having been deposited before the reexcavation of the valley; and he shows that these had been transported by a current from north-west to south-east. From the absence of these gravels in the gorge of the Carboniferous rocks between Hunts Tor, near Chagford, and Clifford Bridge, he considers that that valley has been opened since the time when the boulders and gravels were deposited; and he then shows that the stream from the valley of the Teign, prior to the opening of that valley, passed by Moreton Hampstead to Bovey Tracey. The paper contains notices of the minerals found in the district, and of the Granite veins in the Carboniferous rocks.

\section{Notes on the Geologicat heatures of Madritids. By George Clakr, Esq.}

[Communicated by the Assistant-Secretary.]

(Abridged.)

Madrituds is well known to be of volcanic origin, as is also the neighbouring island of Rćunion, where there exists a volcano in constant activity. There is this great difference between the two islands: Mauritius is surrounded by coral-reefs, which protect nearly the whole of its coast, and by their shelter form excellent harbours, while the coast of Réunion is exposed to the full force of the ocean. The action of the waves is so strong on its shores that not a particle of the basaltic sand which strews them presents an angle. Its beach exhibits nothing but a mass of pebbles, varying in size from a foot or more in diameter to particles almost imperceptible to the naked eye.

The reefs of Mauritius support various islets, which have been generally regarded as forming an integral part of them, though rising to as much as thirty feet above the sea-level.

Gabriel Islet, is partly basaltic and partly calcareous ; and it is on the latter that the late Dr. P. Ayres discovered the fossilized remains of a forest, of which he gave an account at the Meeting of the Royal Society of Arts and Sciences of Mauritius, in 1860.

Egret Island stands on a calcareous bottom surrounded by sand between the reef and the shore, about a mile from the former and 